\title{
Gas exchange, growth, and quality of passion fruit seedlings cultivated with saline water
}

\section{Trocas gasosas, crescimento e qualidade de mudas de maracujazeiro cultivadas com águas salinas}

\author{
Geovani Soares de Lima ${ }^{1 *}$; José Nathanael Ferreira de Andrade ${ }^{2}$; Mizael Nabor Vaz \\ de Medeiros ${ }^{2}$; Lauriane Almeida dos Anjos Soares ${ }^{3}$; Hans Raj Gheyi ${ }^{1}$; Reginaldo \\ Gomes Nobre4; Pedro Dantas Fernandes ${ }^{1}$; Cassiano Nogueira de Lacerda ${ }^{5}$
}

\section{Highlights}

Passion fruit gas exchange is reduced by water salinity from $0.3 \mathrm{dS} \mathrm{m}^{-1}$.

It is possible to obtain seedlings with acceptable quality with water to $3.5 \mathrm{dS} \mathrm{m}^{-1}$

BRS Sol do Cerrado and Guinezinho are moderately sensitive to salt stress.

\begin{abstract}
This study was conducted to evaluate the gas exchange, growth, and quality of passion fruit cultivars under irrigation with waters of different salinity levels. The experiment was conducted in a greenhouse, in Pombal$\mathrm{PB}$, Brazil, using a randomized block design in a $5 \times 2$ factorial arrangement, with five levels of electrical conductivity of irrigation water $\left(0.3,1.1,1.9,2.7\right.$, and $3.5 \mathrm{dS} \mathrm{m}^{-1}$ ) and two passion fruit cultivars (BRS Sol do Cerrado and Guinezinho), with three plants per plot and four replicates. The reduction in transpiration, intercellular $\mathrm{CO}_{2}$ concentration and $\mathrm{CO}_{2}$ assimilation rate in passion fruit plants grown with saline water was related to factors of stomatal and non-stomatal origin. Gas exchange and growth of passion fruit cultivars were negatively affected by water salinity from $0.3 \mathrm{dS} \mathrm{m}^{-1}$ at 75 days after sowing. Despite the reduction in the growth of the passion fruit cultivars, irrigation with water of up to $3.5 \mathrm{dS} \mathrm{m}^{-1}$ could be used to obtain seedlings with acceptable quality. Based on the relative yield of total dry phytomass, the passion fruit cultivars BRS Sol do Cerrado and Guinezinho were classified as moderately sensitive to water salinity during the seedling phase.
\end{abstract}

Key words: Passiflora edulis f. flavicarpa. Salt stress. Tolerance.

1 Profs., Programa de Pós-Graduação em Engenharia Agrícola, Centro de Tecnologia e Recursos Naturais, Universidade Federal de Campina Grande, UFCG, Campina Grande, PB, Brasil. E-mail: geovani.soares@pq.cnpq.br; hans@pq.cnpq. br; pedrodantasfernandes@gmail.com

2 Discentes do Curso de Graduação em Agronomia, UFCG, Centro de Ciências e Tecnologia Agroalimentar, Pombal, PB, Brasil. E-mail: josenathanael29@outlook.com; mizaeldemedeiros@hotmail.com

3 Profa, Unidade Acadêmica de Ciências Agrárias, UFCG, Pombal, PB, Brasil. E-mail: lauriane.soares@pq.cnpq.br

4 Prof., Departamento de Ciências e Tecnologia, Universidade Federal Rural do Semi-Árido, UFERSA, Caraúbas, RN, Brasil. E-mail: rgomesnobre@yahoo.com.br

5 Discente do Curso de Mestrado do Programa de Pós-Graduação em Engenharia Agrícola, UFCG, Centro de Tecnologia e Recursos Naturais, Campina Grande, PB, Brasil. E-mail: cassianonogueiraagro@gmail.com

*Author for correspondence

Received: Sept. 03, 2019 - Approved: Oct. 26, 2020 


\section{Resumo}

Desenvolveu-se este trabalho com o objetivo de avaliar as trocas gasosas, o crescimento e a qualidade de cultivares de maracujazeiro sob irrigação com águas de diferentes níveis salinos. $O$ experimento foi conduzido em casa de vegetação, em Pombal-PB, utilizando-se o delineamento de blocos casualizados em arranjo fatorial 5 × 2, sendo cinco níveis de condutividade elétrica da água de irrigação $(0,3 ; 1,1 ; 1,9 ; 2,7$ e 3,5 $\mathrm{dS} \mathrm{m}^{-1}$ ) e duas cultivares de maracujazeiro (BRS Sol do Cerrado e Guinezinho), com três plantas por parcela e quatro repetições. A redução na transpiração, concentração intercelular de $\mathrm{CO}_{2}$ e taxa de assimilação de $\mathrm{CO}_{2}$ nas plantas de maracujazeiro cultivadas com águas salinas está relacionado a fatores de origem estomáticos e não estomáticos. As trocas gasosas e o crescimento das cultivares de maracujazeiro foram afetados de forma negativa pela salinidade da água a partir de $0,3 \mathrm{dS} \mathrm{m}^{-1}$, aos 75 dias após o semeio. Apesar da redução no crescimento nas cultivares de maracujazeiro, a irrigação com água de até $3,5 \mathrm{dS} \mathrm{m}^{-1}$ pode ser utilizada para obtenção de mudas com qualidade aceitável. Com base no rendimento relativo de fitomassa seca total, as cultivares de maracujazeiro BRS Sol do Cerrado e Guinezinho foram classificados como moderadamente sensível a salinidade da água na fase de formação de mudas.

Palavras-chave: Passiflora edulis f. flavicarpa. Estresse salino. Tolerância.

\section{Introduction}

Passion fruit (Passiflora edulis $\mathrm{f}$. flavicarpa) is recognized as a fruit crop of great socioeconomic importance in Brazil, and this relevance is associated with the favorable edaphoclimatic conditions for its cultivation as well as the physico-chemical characteristics of the fruits and the great acceptance of its juice and fresh fruit in the national market $(\mathrm{J}$. D. Bezerra, Pereira, Silva, \& Raposo, 2016). The area occupied by the yellow passion fruit crop in 2018 was 43,248 hectares, with a total production of 602,651 tons; the Northeast region was the greatest producer, with 375,541 tons, followed by the Southeast region, which produced 97,307 tons. However, the mean yield obtained in the Northeast region was $12.886 \mathrm{~kg} \mathrm{ha}^{-1}$ while in the Southeast region it was $17.047 \mathrm{~kg} \mathrm{ha}^{-1}$ (Instituto Brasileiro de Geografia e Estatística [IBGE], 2018).

Among the factors that contribute to the lower yield of this crop in the Northeast region, the lower technological level of the orchards and the quantitative and qualitative reduction in water availability have particular relevance. This region is characterized by high evaporation rates, irregular rainfall, and poor drainage in the soil. Thus, the waters have an electrical

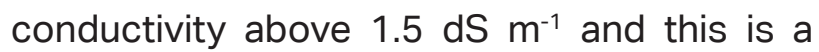
limiting factor in agricultural production, due to the resulting morphological, physiological, and biochemical changes that occur in plants and compromise their growth, production, and fruit quality (Freire, Dias, Cavalcante, Fernandes, \& Lima, 2014; I. L. Bezerra, Nobre, Gheyi, Lima, \& Barbosa, 2018a).

Under saline conditions, gas exchange and water absorption are negatively affected because salt stress causes a reduction in stomatalconductanceand, consequently, lower carbon assimilation, phytomass production, and a lower yield. In addition, it promotes changes in photochemical parameters and carbon metabolism (I. L. Bezerra et al., 2018b). Osmotic stress is associated with oxidative 
stress and the production of reactive oxygen species (ROS). Overproduction of ROS under stress conditions can damage cellular components, including DNA, proteins, and membrane lipids (Filek et al., 2012). However, the severity with which salt stress affects plants depends on its magnitude and duration.

Although the Northeast region stands out as the largest producer of yellow passion fruit, the high salinity of soils and water in several areas of the region has compromised the production of good quality seedlings and the establishment of this crop under conventional management, since it is sensitive to water salinity (J. D. Bezerra et al., 2016). However, the tolerance of plants to salt stress depends on the species, cultivar, management practices of irrigation, fertilization, climatic conditions, and the type of salts present in the water.

The production of seedlings should be considered a fundamental step in the establishment of the orchard because the quality of seedlings is closely related to the production potential of the crop (Mesquita et al., 2015). Thus, adopting management strategies that enable the establishment of crops under salt stress conditions is extremely important, especially in the semi-arid region of Northeastern Brazil. Among these strategies, it is essential to identify cultivars that are tolerant to salt stress, especially when soil salinity cannot be maintained at low levels (Brito et al., 2014).

In view of the above, this study was conducted to evaluate the gas exchange, growth, and quality of seedlings of passion fruit cultivars under irrigation with waters of different salinity levels.

\section{Materials and Methods}

The experiment was carried out in a protected environment (greenhouse) at the Center for Science and Agri-Food Technology (CCTA) of the Federal University of Campina Grande (UFCG), located in the municipality of Pombal, Paraíba, Brazil, at the geographic coordinates $6^{\circ} 47^{\prime} 20^{\prime \prime}$ South latitude and $37^{\circ} 48^{\prime} 01^{\prime \prime}$ West longitude, and at an altitude of $194 \mathrm{~m}$.

The experimental design was randomized blocks in a $5 \times 2$ factorial arrangement, corresponding to five levels of electrical conductivity of irrigation water $\operatorname{ECw}\left(0.3,1.1,1.9,2.7\right.$, and $\left.3.5 \mathrm{dS} \mathrm{m}^{-1}\right)$ and two passion fruit cultivars - C (BRS Sol do Cerrado and Guinezinho), with three plants per plot and four replicates.

The cultivar BRS Sol do Cerrado produces large yellow fruits with an oblong shape, weighing from 150 to $350 \mathrm{~g}$, and with a pulp yield of around $38 \%$. It has tolerance to leaf diseases, such as bacteriosis, anthracnose, and viruses Empresa Brasileira de Pesquisa Agropecuária [EMBRAPA] (2008). Guinezinho is a yellow passion fruit cultivar traditionally cultivated in the municipality of Nova Floresta - PB, and is known by that name because of the spots present on the rind similar to those present on the feathers of a bird known as guinea fowl (Medeiros et al., 2016).

To obtain the passion fruit seedlings, sowing was carried out by placing 2 seeds in polyethylene containers with dimensions of 15 $\times 30 \mathrm{~cm}$, filled with a 2:1:1 (based on volume) ratio of Neossolo (Entisol) with a loamy sand texture, sand, and organic matter (well-aged cattle manure). The soil came from the rural area of the municipality of São Domingos, 
PB, from 0-15 cm depth. The recipients were equidistantly distributed and supported on benches at $0.80 \mathrm{~m}$ height from the soil. Physical and chemical characteristics of the soil were obtained according to the methodology proposed by Teixeira, Donagemma, Fontana and Teixeira (2017) and are shown in Table 1.

\section{Table 1}

Chemical and physical characteristics of the substrate used in the experiment, before the application of the treatments

\begin{tabular}{|c|c|c|c|c|c|c|c|c|}
\hline \multicolumn{9}{|c|}{ Chemical characteristics } \\
\hline $\left.\mathrm{pH} \mathrm{H}_{2} \mathrm{O}\right)$ & $\mathrm{OM}$ & $\mathrm{P}$ & $\mathrm{K}^{+}$ & $\mathrm{Na}^{+}$ & $\mathrm{Ca}^{2+}$ & $\mathrm{Mg}^{2+}$ & $\mathrm{Al}^{3+}$ & $\mathrm{H}^{+}$ \\
\hline$(1: 2.5)$ & $\mathrm{g} \mathrm{kg}^{-1}$ & $\left(\mathrm{mg} \mathrm{kg}^{-1}\right)$ & \multicolumn{6}{|c|}{ 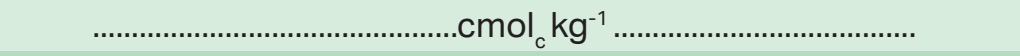 } \\
\hline 7.00 & 3.80 & 11.99 & 0.21 & 0.09 & 2.42 & 5.84 & 0.00 & 0.00 \\
\hline \multicolumn{4}{|c|}{.......... Chemical characteristics ............. } & \multicolumn{5}{|c|}{ 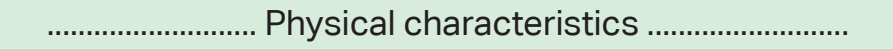 } \\
\hline $\mathrm{EC}_{\mathrm{se}}$ & CEC & SAR & ESP & \multicolumn{3}{|c|}{ Size fraction $\left(\mathrm{g} \mathrm{kg}^{-1}\right)$} & \multicolumn{2}{|c|}{ Water content (dag kg-1) } \\
\hline$\left(\mathrm{dS} \mathrm{m} \mathrm{m}^{-1}\right)$ & $\mathrm{cmol}_{\mathrm{c}} \mathrm{kg}^{-1}$ & $\left.(\mathrm{mmol} \mathrm{L})^{-1}\right)^{0.5}$ & $\%$ & Sand & Silt & Clay & $33.42 \mathrm{kPa}^{1}$ & $1519.5 \mathrm{kPa}^{2}$ \\
\hline 0.75 & 8.56 & 0.94 & 1.05 & 853.00 & 130.70 & 16.30 & 11.66 & 4.23 \\
\hline
\end{tabular}

$\mathrm{pH}$ - Hydrogen potential, OM - Organic matter: Walkley-Black Wet Digestion; $\mathrm{Ca}^{2+}$ and $\mathrm{Mg}^{2+}$ extracted with $1 \mathrm{M} \mathrm{KCl}$ at $\mathrm{pH}$ 7.0; $\mathrm{Na}^{+}$and $\mathrm{K}^{+}$extracted with $1 \mathrm{M} \mathrm{NH}_{4} \mathrm{OAc}$ at $\mathrm{pH} 7.0 ; \mathrm{Al}^{3+}+\mathrm{H}^{+}$extracted with $0.5 \mathrm{M} \mathrm{CaOAc}$ at $\mathrm{pH}$ 7.0; ECse - Electrical conductivity of the saturation extract; $\mathrm{CEC}$ - Cation exchange capacity; SAR - Sodium adsorption ratio of the saturation extract; ESP - Exchangeable sodium percentage; ${ }^{1,2}$ referring to the limits of field capacity and permanent wilting point, respectively.

Fertilization with NPK was performed as a top-dressing, according to the recommendation of Novais, Neves and Barros (1991), applying 100, 300, and $150 \mathrm{mg} \mathrm{kg}^{-1}$ of soil of $\mathrm{N}_{1} \mathrm{P}_{2} \mathrm{O}_{5}$, and $\mathrm{K}_{2} \mathrm{O}$, respectively, in the form of urea $(45 \% \mathrm{~N})$, monoammonium phosphate $\left(12 \% \quad \mathrm{~N}, 54 \% \mathrm{P}_{2} \mathrm{O}_{5}\right)$ and potassium chloride $\left(60 \% \mathrm{~K}_{2} \mathrm{O}\right)$ through the irrigation water at 15,30 , and 45 days after sowing (DAS). Micronutrient fertilization was performed at 20,40, and 60 DAS, using Ubyfol solution at a concentration of $1.0 \mathrm{~g} \mathrm{~L}^{-1}$.

The water used as the lowest salinity treatment $\left(0.3 \mathrm{dS} \mathrm{m}^{-1}\right)$ came from the public supply system of Pombal - PB. The other salinity levels were prepared in such a way to have an equivalent proportion of 7:2:1 of $\mathrm{Na}^{+}: \mathrm{Ca}^{2+}: \mathrm{Mg}^{2+}$, respectively, using the salts $\mathrm{NaCl}, \mathrm{CaCl}_{2} \cdot 2 \mathrm{H}_{2} \mathrm{O}$, and $\mathrm{MgCl}_{2} \cdot 6 \mathrm{H}_{2} \mathrm{O}$. This is the ratio that commonly prevails in sources of water used for irrigation in small farms in the Brazilian Northeast (Medeiros, 1992). Irrigation water with higher levels of salinity were prepared considering the relationship between ECW and concentration of salts according to Richards (1954), Eq. 1:

$\mathrm{Q}\left(\right.$ mmolc $\left.\mathrm{L}^{-1}\right)=10 \times \mathrm{ECw}\left(\mathrm{dS} \mathrm{m}^{-1}\right)$

where:

$\mathrm{Q}=$ Quantity of salts to be applied $\left(\mathrm{mmol}_{\mathrm{C}} \mathrm{L}^{-1}\right)$;

$\mathrm{ECw}=$ Electrical conductivity of the water (dS $\left.\mathrm{m}^{-1}\right)$ 
After sowing, irrigation was performed manually, applying in each container a volume corresponding to that obtained by water balance (applied water - drained water) plus a leaching fraction of $15 \%$, based on Eq. 2:

$$
\mathrm{VI}=\frac{(\mathrm{Va}-\mathrm{Vd})}{(1-\mathrm{LF})}
$$

Where:

$\mathrm{VI}=$ Water volume to be used in the irrigation event $(\mathrm{mL}) ; \mathrm{Va}=$ water volume applied in the previous irrigation event $(\mathrm{mL}) ; \mathrm{Vd}=$ water volume drained $(\mathrm{mL})$ and $\mathrm{LF}=$ leaching fraction of 0.15 .

At 75 days after sowing (DAS), gas exchange was evaluated in passion fruit plants through stomatal conductance (gs) (mol $\mathrm{H}_{2} \mathrm{O}$ $\left.\mathrm{m}^{-2} \mathrm{~s}^{-1}\right)$, transpiration $(E)\left(\mathrm{mmol} \mathrm{H}_{2} \mathrm{O} \mathrm{m}^{-2} \mathrm{~s}^{-1}\right), \mathrm{CO}_{2}$ assimilation rate $(A)\left(\mu \mathrm{mol} \mathrm{m} \mathrm{m}^{-2} \mathrm{~s}^{-1}\right)$, and internal $\mathrm{CO}_{2}$ concentration $(\mathrm{Cl})$ ( $\left.\mu \mathrm{mol} \mathrm{H}_{2} \mathrm{O} \mathrm{m}^{-2} \mathrm{~s}^{-1}\right)$. Readings were performed with an infrared gas analyzer (IRGA, Infra-Red Gas Analyser, model LCpro - SD), from ADC BioScientific, UK, with a constant light of $1.200 \mu \mathrm{mol}$ of photons $\mathrm{m}^{-2}$ $\mathrm{s}^{-1}$, measured on the third fully expanded leaf counted from the apical bud.

Growth was measured based on plant height $(\mathrm{PH})$, stem diameter (SD), leaf area (LA), leaf dry phytomass (LDP), stem dry phytomass (StDP), root dry phytomass (RDP), shoot dry phytomass (ShDP) and total dry phytomass (TDP). Seedling quality was assessed using the Dickson Quality Index (DQI). Plant height was measured as the distance from the plant collar to the insertion of the apical meristem. The stem diameter was measured at $5 \mathrm{~cm}$ from the plant collar. The leaf area was obtained by measuring the length and width of all leaves of the plants, according to the methodology described by Cavalcante et al. (2002), as shown in Eq 3:

$\mathrm{LA}=\sum 0.81 \mathrm{x}$

where:

$\mathrm{LA}=$ Leaf area $\left(\mathrm{cm}^{2}\right)$ and $\mathrm{x}=$ product between leaf length and leaf width $\left(\mathrm{cm}^{2}\right)$.

Plants were cut close to the soil surface to determine their phytomass and separated into leaves, stem, and roots. Subsequently, the different parts (leaves, stem, and roots) were placed in a paper bag and dried in an oven with forced air ventilation at a temperature of $65^{\circ} \mathrm{C}$ until a constant weight was observed. Then, this material was weighed to obtain LDP, StDP, RDP, and ShDP, which was summed with RDP to obtain TDP.

The quality of passion fruit seedlings was determined using the Dickson Quality Index - DQI, according to Dickson, Leaf and Hosner (1960), Eq. 4:

$\mathrm{DQI}=\frac{(\mathrm{TDP})}{(\mathrm{PH} / \mathrm{SD})+(\mathrm{ShDP} / \mathrm{RDP})}$

The data were subjected to an analysis of variance by $\mathrm{F}$ test and, when significant, a polynomial regression analysis was performed for the salinity level factor and a means comparison test (Tukey at 0.05 probability level) for the cultivars. When there was significant interaction between the factors, the salinity level factor was decomposed for each cultivar, using the statistical software SISVARESAL (Ferreira, 2011). 


\section{Results and Discussion}

There was a significant effect of water salinity levels on stomatal conductance, transpiration, intercellular $\mathrm{CO}_{2}$ concentration, $\mathrm{CO}_{2}$ assimilation rate, plant height, stem diameter, and leaf area of passion fruit cultivars (Table 2). The cultivars did not significantly influence any of the variables analyzed. The interaction between factors (SL $\times$ C) significantly affected only the height of passion fruit plants, at 65 DAS. A. A. R. da Silva et al. (2019), evaluating the photosynthetic efficiency and growth of yellow passion fruit cultivated under different levels of irrigation water salinity ( $\mathrm{ECW}$ of 0.7 to $2.8 \mathrm{dS} \mathrm{m}^{-1}$ ), found that salt stress significantly influenced the $\mathrm{CO}_{2}$ assimilation rate and transpiration, at 61 and 96 DAS, stem diameter at 35, 73 and 105 DAS, and number of leaves at 35 DAS.

\section{Table 2}

Summary of the analysis of variance for stomatal conductance (gs), transpiration $(E)$, intercellular $\mathrm{CO}_{2}$ concentration $(\mathrm{C}), \mathrm{CO}_{2}$ assimilation rate (A), plant height (PH), stem diameter (SD) and leaf area (LA) of passion fruit cultivars irrigated with saline waters at 75 days after sowing

\begin{tabular}{|cccccccc|}
\hline \multirow{2}{*}{ Source of variation } & \multicolumn{7}{c|}{ Mean squares } \\
\cline { 2 - 8 } & gs & $E$ & $C i$ & $A$ & PH & SD & LA \\
\hline Saline levels (SL) & $0.003^{* *}$ & $3.85^{* *}$ & $12650.08^{* *}$ & $18.77^{* *}$ & $1632.19^{* *}$ & $17.24^{* *}$ & $850745.92^{* *}$ \\
\hline Linear regression & $0.012^{* *}$ & $13.77^{* *}$ & $34376.14^{* *}$ & $72.42^{* *}$ & $6155.66^{* *}$ & $67.32^{* *}$ & $3290206.92^{* *}$ \\
\hline Quadratic regression & $0.002^{*}$ & $1.28^{*}$ & $10177.65^{*}$ & $1.22^{\text {ns }}$ & $326.57^{*}$ & $1.22^{\text {ns }}$ & $94745.55^{\text {ns }}$ \\
\hline Cultivars (C) & $0.0003^{\text {ns }}$ & $0.04^{\text {ns }}$ & $592.82^{\text {ns }}$ & $0.30^{\text {ns }}$ & $648.02^{*}$ & $0.40^{\text {ns }}$ & $8254.12^{\text {ns }}$ \\
\hline Interaction (SL x C) & $0.0001^{\text {ns }}$ & $0.06^{\text {ns }}$ & $1047.03^{\text {ns }}$ & $1.15^{\text {ns }}$ & $308.43^{*}$ & $1.23^{\text {ns }}$ & $31585.79^{\text {ns }}$ \\
\hline Blocks & $0.0003^{\text {ns }}$ & $0.04^{\text {ns }}$ & $2004.29^{\text {ns }}$ & $0.79^{\text {ns }}$ & 16.98 & $0.31^{\text {ns }}$ & $6506.47^{\text {ns }}$ \\
\hline Residual & 0.00001 & 0.10 & 686.61 & $0.87^{\text {ns }}$ & 88.61 & 0.32 & 15135.93 \\
CV (\%) & 32.68 & 29.94 & 15.17 & 17.16 & 11.59 & 10.64 & 11.20 \\
\hline
\end{tabular}

$n \mathrm{~ns}^{*}{ }^{*}{ }^{* *}$ - respectively not significant, significant at $\mathrm{p}<0.05$ and at $\mathrm{p}<0.01$.

The stomatal conductance of passion fruit plants decreased quadratically with increasing water salinity (Figure 1A). Plants grown under water salinity of $0.3 \mathrm{dS} \mathrm{m}^{-1}$ showed the maximum estimated value of $0.0746 \mathrm{~mol}$ $\mathrm{H}_{2} \mathrm{O} \mathrm{m}^{-2} \mathrm{~s}^{-1}$, which reduced from this ECw level, and the minimum value of $0.0229 \mathrm{~mol} \mathrm{H}_{2} \mathrm{O}$ $\mathrm{m}^{-2} \mathrm{~s}^{-1}$ was reached by those irrigated under the highest water salinity level (3.0 dS $\left.\mathrm{m}^{-1}\right)$. By comparing the transpiration of plants subjected to $E C w$ of $0.3 \mathrm{dS} \mathrm{m}^{-1}$ to that of plants under water salinity of $3.5 \mathrm{dS} \mathrm{m}^{-1}$, it was possible to note a reduction of $0.0493 \mathrm{~mol} \mathrm{H}_{2} \mathrm{O} \mathrm{m} \mathrm{m}^{-2} \mathrm{~s}^{-1}$. Under salt stress conditions, plants close their stomata in response to the decrease in leaf turgor, high vapor pressure deficit in the atmosphere or chemical signals generated by the roots. Thus, the supply of $\mathrm{CO}_{2}$ to RuBisCO is hampered, which predisposes the photosynthetic apparatus to increased energy dissipation and a negative regulation of photosynthesis when plants are subjected to high light and temperature. However, in plants under mild stress, a small decrease in stomatal conductance can have 
protective effects against stress, enabling the plant to save water and improve water use efficiency (Chaves, Flexas, \& Pinheiro, 2009).

Leaf transpiration of passion fruit plants decreased with increases in the levels of water electrical conductivity (Figure 1B), and its maximum estimated value of $2.11 \mathrm{mmol} \mathrm{H}_{2} \mathrm{O}$ $\mathrm{m}^{-2} \mathrm{~s}^{-1}$ was obtained in plants grown under ECW of $0.3 \mathrm{dS} \mathrm{m}^{-1}$ and the minimum value of 0.45 mmol $\mathrm{H}_{2} \mathrm{O} \mathrm{m} \mathrm{m}^{-2} \mathrm{~s}^{-1}$ was obtained in those that were irrigated using water with salinity of 3.5 $\mathrm{dS} \mathrm{m}^{-1}$. The transpiration of plants subjected to ECW of $3.5 \mathrm{dS} \mathrm{m}^{-1}$ decreased by $1.66 \mathrm{mmol}$ $\mathrm{H}_{2} \mathrm{O} \mathrm{m} \mathrm{m}^{-2} \mathrm{~s}^{-1}$ compared to those under the lowest water salinity level $\left(0.3 \mathrm{dS} \mathrm{m}^{-1}\right)$. Water loss by plants is regulated by the activity of the guard cells. Therefore, the reduction in leaf transpiration results from stomatal closure and aims to reduce the susceptibility of the plant to dehydration and excessive absorption of toxic ions ( $\mathrm{Na}^{+}$and $\mathrm{Cl}^{-}$), an important mechanism under salt stress conditions. Andrade et al. (2019), in a study carried out to evaluate the photosynthetic efficiency and growth of yellow passion fruit under different levels of water salinity (ECw from 0.7 to $2.8 \mathrm{dS} \mathrm{m}^{-1}$ ), concluded that water salinity inhibited transpiration at 61 and 96 days after transplanting.
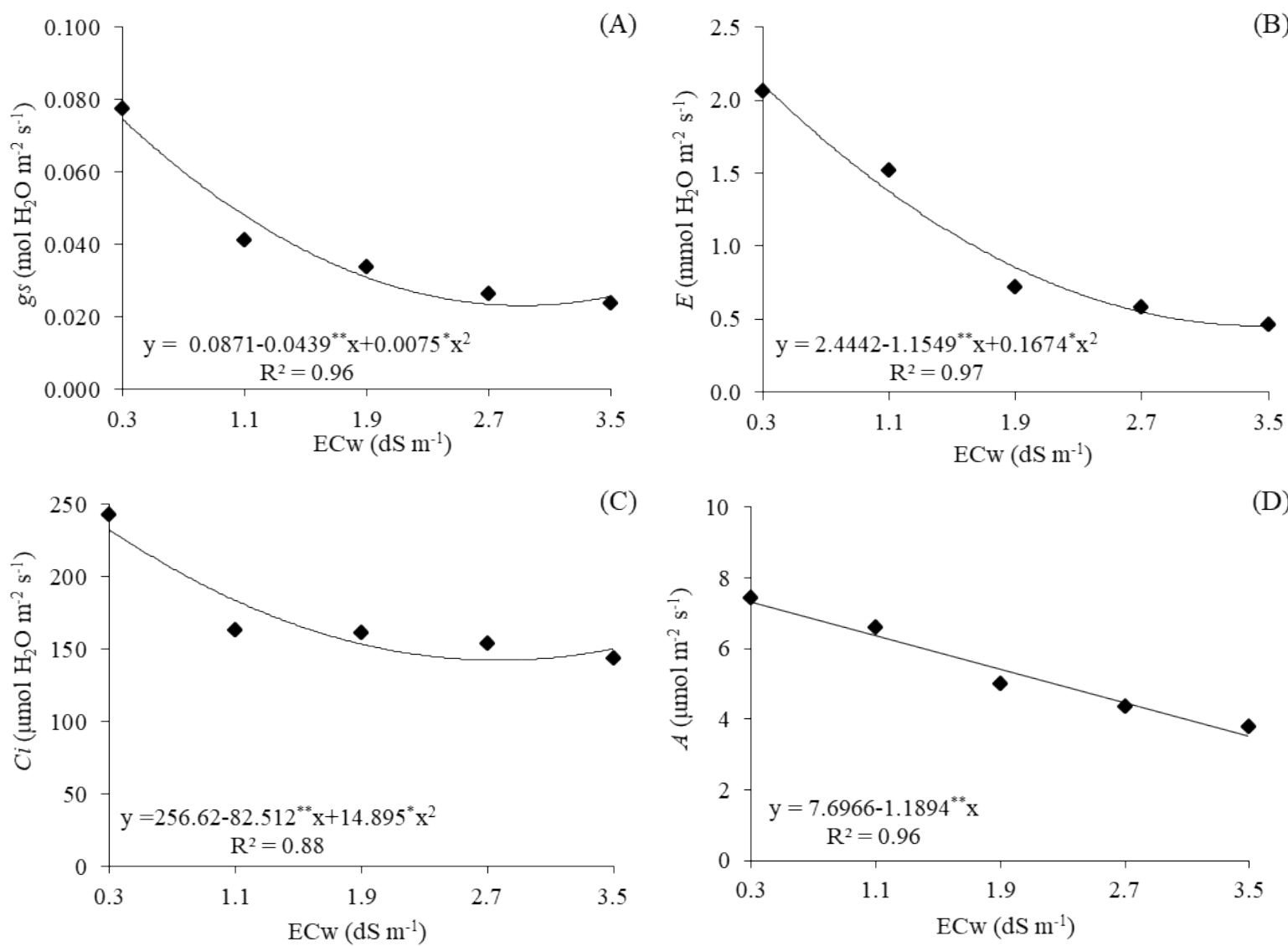

(D)

Figure 1.Stomatal conductance-gs $(\mathrm{A})$, transpiration- $E(\mathrm{~B})$, intercellular $\mathrm{CO}_{2}$ concentration - $\mathrm{Ci}(\mathrm{C})$ and $\mathrm{CO}_{2}$ assimilation rate $-A$ (D) of passion fruit cultivars as a function of water salinity - ECw, at 75 days after sowing.

${ }^{*},{ }^{* *}$ - respectively, significant at $p<0.05$ and at $p<0.01$. 
Water salinity reduced the intercellular $\mathrm{CO}_{2}$ concentration of passion fruit plants, with intracellular $\mathrm{CO}_{2}$ decreasing as the $\mathrm{ECW}$ increased (Figure 1C). Plants subjected to a

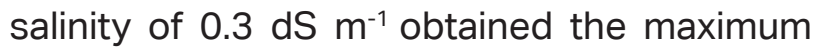
estimated value of $233.20 \mu \mathrm{mol} \mathrm{H}_{2} \mathrm{O} \mathrm{m}^{-2} \mathrm{~s}^{-1}$, which decreased sharply, and the lowest $\mathrm{Ci}$ (150.29 $\mu \mathrm{mol} \mathrm{H}_{2} \mathrm{O} \mathrm{m}^{-2} \mathrm{~s}^{-1}$ ) was obtained in those that were under irrigation with ECw of 3.5 dS $\mathrm{m}^{-1}$. Comparatively, plants grown under an ECw of $3.5 \mathrm{dS} \mathrm{m}^{-1}$ had a reduction in Ci of $82.91 \mu \mathrm{mol}$ $\mathrm{H}_{2} \mathrm{O} \mathrm{m}^{-2} \mathrm{~s}^{-1}$ compared to those that received the lowest level of water salinity $\left(0.3 \mathrm{dS} \mathrm{m}^{-1}\right)$. The decrease in the internal $\mathrm{CO}_{2}$ concentration is a consequence of stomatal closure (Figure 1A) and stands out as one of the main mechanisms responsible for the reduction in the $\mathrm{CO}_{2}$ assimilation rate, due to the reduction in the normal flow of $\mathrm{CO}_{2}$ towards the carboxylation site (Bosco, Oliveira, Hernandez, \& Lacerda, 2009).

The $\mathrm{CO}_{2}$ assimilation rate of passion fruit plants was also negatively affected by salt stress (Figure 1D), with a linear decrease observed; water salinity levels decreased the assimilation rate by $15.45 \%$ per unit increase in $\mathrm{ECw}$. In relative terms, plants grown under ECw of $3.5 \mathrm{dS} \mathrm{m}^{-1}$ reduced their $A$ by $51.85 \%$ (3.80 $\mu \mathrm{mol} \mathrm{H}_{2} \mathrm{O} \mathrm{m}^{-2} \mathrm{~s}^{-1}$ ) compared to those subjected to the lowest salinity level (0.3 dS $\mathrm{m}^{-1}$ ). The reduction in $\mathrm{CO}_{2}$ assimilation rate in plants grown under salt stress occurs due to stomatal closure to reduce water loss, which in turn leads to reductions in leaf transpiration rates and intercellular $\mathrm{CO}_{2}$ concentration in the leaves (Altuntas, Dasgan, \& Akhoundnejad, 2018), promoting a decrease in $\mathrm{CO}_{2}$ availability for carboxylation (E. N. da Silva, Ribeiro, Ferreira-Silva, Viégas, \& Silveira, 2011).

The height of passion fruit plants was significantly influenced by the interaction between factors ( $S L \times C$ ). According to the regression equations (Figure $2 \mathrm{~A}$ ), there were reductions in the $\mathrm{PH}$ of the cultivars BRS Sol do Cerrado and Guinezinho of 13.99 and 8.10\% per unit increase in ECw, respectively. In a comparison between the passion fruit cultivars, BRS Sol do Cerrado obtained the highest reduction $(47.07 \mathrm{~cm})$ of growth in plant height, while the lowest decrease (26.15 $\mathrm{cm}$ ) was observed in the cultivar Guinezinho, suggesting that the former is the most sensitive to salt stress. It is known that the availability of water for plants grown under saline conditions is reduced due to the decrease in osmotic and water potentials existing in the root environment. With the reduction in water absorption there is a decrease in leaf turgor and subsequent closure of stomata, leading to reductions in transpiration and photosynthesis and, consequently, inhibition of plant growth (Mastrogiannidou et al., 2016). 

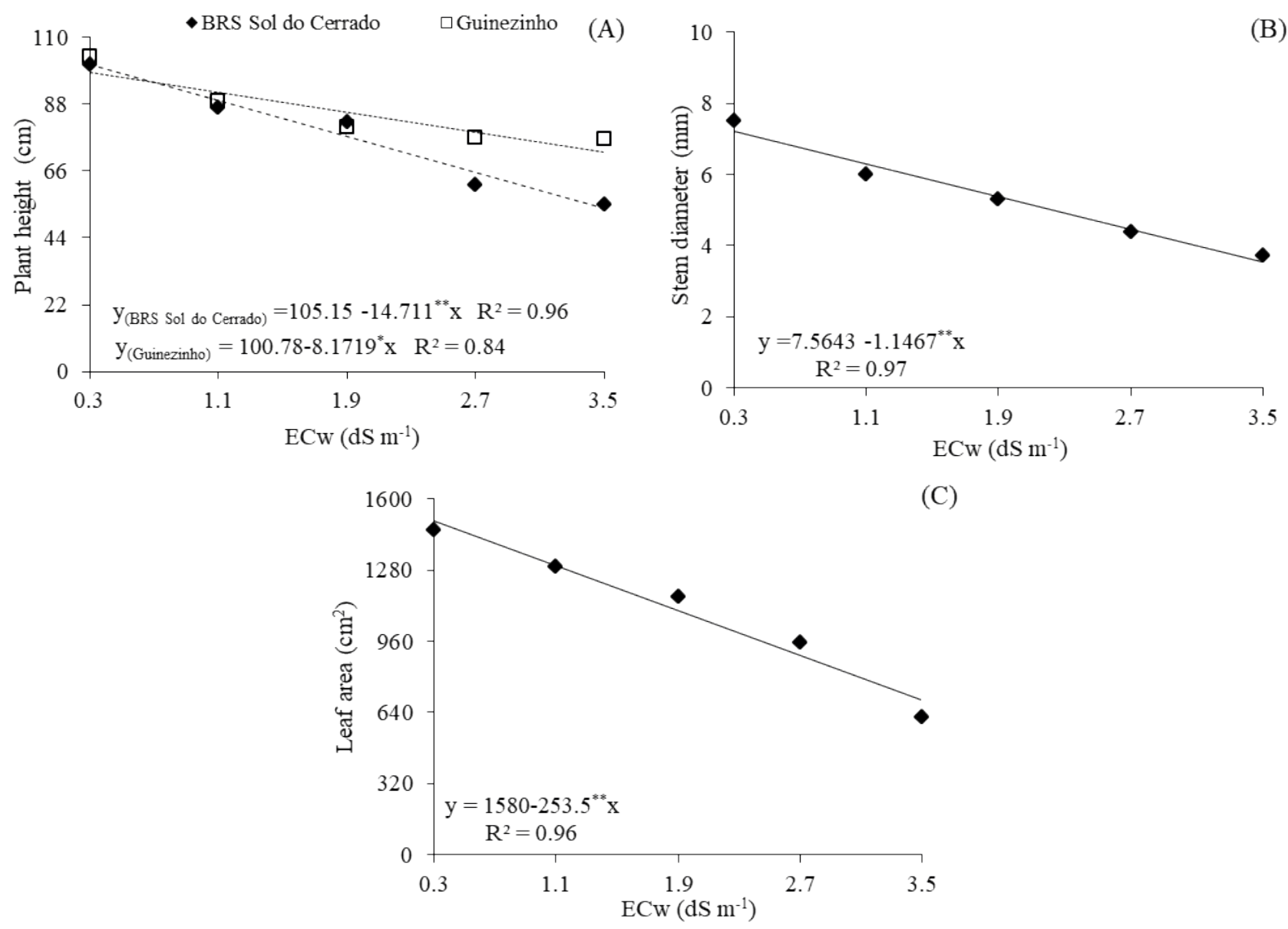

Figure 2. Plant height $(A)$ as a function of the interaction between water salinity levels - ECw and passion fruit cultivars and stem diameter $(B)$ and leaf area $(C)$ of plants grown under different levels of ECw, at 75 days after sowing.

${ }^{*}, * *$ - respectively, significant at $p<0.05$ and at $p<0.01$.

The stem diameter of passion fruit plants decreased sharply with increases in the electrical conductivity of water (Figure 2B), by $15.15 \%$ per unit increase in ECw. Plants subjected to water salinity of $3.5 \mathrm{dS} \mathrm{m}^{-1}$ had a reduced growth (in SD) of $3.66 \mathrm{~mm}$ (50.82\%) compared to those irrigated with the lowest level of ECW $\left(0.3 \mathrm{dS} \mathrm{m}^{-1}\right)$. The decrease in plant growth is related to the reduction in soil water potential (osmotic phase) and, subsequently, an ionic phase due to excessive absorption of toxic ions, especially $\mathrm{Na}^{+}$and $\mathrm{Cl}^{-}$(AcostaMotos et al., 2017). Salt stress leads to a reduction in photosynthetic activity, changes in enzyme activities, oxidative stress, disrupts the structure and function of the biochemical membrane, and destroys ultrastructural cellular components (Mastrogiannidou et al., 2016).

The leaf area of passion fruit plants was linearly reduced in response to the increase in water salinity levels (Figure 2C), by $16.04 \%$ 
per unit increase in ECw. By comparing the leaf area of plants irrigated using water with electrical conductivity of $3.5 \mathrm{dS} \mathrm{m}^{-1}$ with that of plants subjected to the lowest salinity level $(0.3$ $\left.\mathrm{dS} \mathrm{m}^{-1}\right)$, it was possible to observe a reduction of $53.93 \%\left(811.20 \mathrm{~cm}^{2}\right)$. Plants exposed to salt stress usually have a reduced leaf area in order to minimize water losses to the atmosphere and maintain cellular turgor by reducing transpiration (Oliveira et al., 2013). In addition, the reduction in the growth in leaf area may be related to the decrease in $\mathrm{CO}_{2}$ assimilation rate and excessive absorption of salts, affecting the production of specific metabolites that directly inhibit growth (Acosta-Motos et al.,
2017). Lima, Fernandes, Soares, Gheyi and Fernandes (2020a), in a study with the passion fruit cv. 'BRS Rubi do Cerrado' under irrigation with saline waters (ECw from 0.3 to $3.5 \mathrm{dS} \mathrm{m}^{-1}$ ), found that ECw from $0.3 \mathrm{dS} \mathrm{m}^{-1}$ reduced the growth in leaf area by $10.36 \%$ per unit increase in $\mathrm{ECW}$, at 40 days after sowing.

According to the summary of the analysis of variance (Table 3), there was a significant effect of water salinity levels on all variables analyzed at 75 days after sowing. The cultivars factor did not influence any of the variables measured. The interaction between factors $(S L \times C)$ significantly affected only the Dickson Quality Index of passion fruit plants.

Table 3

Summary of the analysis of variance for leaf dry phytomass (LDP), stem dry phytomass (StDP), root dry phytomass (RDP), shoot dry phytomass (ShDP), total dry phytomass (TDP) and Dickson Quality Index (DQI) of passion fruit cultivars irrigated with saline waters at 75 days after sowing

\begin{tabular}{|c|c|c|c|c|c|c|}
\hline \multirow{2}{*}{ Source of variation } & \multicolumn{6}{|c|}{ Mean squares } \\
\hline & LDP & StDP & RDP & ShDP & TDP & DQI \\
\hline Saline levels (SL) & $52.64^{* *}$ & $4.56^{* *}$ & $6.58^{* *}$ & $85.14^{* *}$ & $133.41^{* *}$ & $0.64^{* *}$ \\
\hline Linear regression & $206.94^{* *}$ & $15.74^{* *}$ & $20.80^{* *}$ & $336.85^{* *}$ & $524.85^{\star *}$ & $2.39^{* *}$ \\
\hline Quadratic regression & $2.17^{\text {ns }}$ & $0.87^{\text {ns }}$ & $4.13^{* *}$ & $0.29^{\text {ns }}$ & $2.23^{\text {ns }}$ & $0.11^{\text {ns }}$ \\
\hline Cultivars (C) & $0.42^{\text {ns }}$ & $0.49^{\text {ns }}$ & $0.05^{\text {ns }}$ & $1.83^{\text {ns }}$ & $2.53^{\text {ns }}$ & $0.11^{\text {ns }}$ \\
\hline Interaction (SL x C) & $2.91^{\mathrm{ns}}$ & $0.82^{\text {ns }}$ & $0.05^{\mathrm{ns}}$ & $1.15^{\mathrm{ns}}$ & $1.53^{\text {ns }}$ & $0.04^{*}$ \\
\hline Blocks & $0.68^{\text {ns }}$ & $0.37^{\mathrm{ns}}$ & $0.10^{\text {ns }}$ & $0.92^{\text {ns }}$ & $1.51^{\mathrm{ns}}$ & $0.01^{\text {ns }}$ \\
\hline Residual & 1.49 & 0.54 & 0.20 & 2.00 & 2.21 & 0.41 \\
\hline CV (\%) & 9.14 & 19.37 & 17.36 & 8.25 & 7.54 & 13.62 \\
\hline
\end{tabular}

$n \mathrm{~ns}^{*},{ }^{* *}$ - respectively not significant, significant at $\mathrm{p}<0.05$ and at $\mathrm{p}<0.01$. 
The leaf dry phytomass and stem dry phytomass of passion fruit plants decreased linearly with increases in the levels of irrigation water salinity (Figure 3A and 3B), with reductions of 11.70 and $11.43 \%$ per unit increase in $\mathrm{ECW}$, respectively. When irrigated with an ECW of $3.5 \mathrm{dS} \mathrm{m}^{-1}$, passion fruit plants exhibited reductions of 6.43 and $1.77 \mathrm{~g} / \mathrm{plant}$ in LDP and StDP compared to those subjected to the lowest salinity level $\left(0.3 \mathrm{dS} \mathrm{m}^{-1}\right)$. The decrease in phytomass accumulation is a consequence of the decrease in $\mathrm{CO}_{2}$ assimilation rate (Figure 1D) imposed by salt stress. The low availability of water due to the reduction in the osmotic potential caused by high salt concentration causes stomatal closure and, consequently, reduces the photosynthetic rate through the action of stomatal and non-stomatal factors. Thus, to maintain homeostasis, plants require a considerable consumption of energy to maintain sodium compartmentalization, in both cells and organs. Thus, the association of these factors is determinant for the reduction in phytomass accumulation (Willadino, Gomes, Silva, Martins, \& Camara, 2011).
Water salinity inhibited the root dry phytomass accumulation of passion fruit plants in a quadratic manner (Figure 3C); the maximum estimated value of $3.98 \mathrm{~g} / \mathrm{plant}$ was observed in plants subjected to ECw of $0.3 \mathrm{dS} \mathrm{m}^{-1}$, reducing from this salinity level and reaching the lowest RDP (1.85 g/plant) in

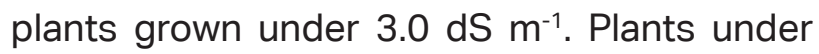
irrigation using water with salinity of $3.5 \mathrm{dS} \mathrm{m}^{-1}$ reduced their RDP by $2.04 \mathrm{~g} / \mathrm{plant}$ compared to those that received the lowest level of ECW $\left(0.3 \mathrm{dS} \mathrm{m}^{-1}\right)$. Such a decrease in RDP can be considered a strategy that plants use to reduce the absorption of toxic ions, especially $\mathrm{Na}^{+}$ and $\mathrm{Cl}^{-}$, and their consequent transport to the aerial part of the plant, hampering plant growth (Sá, Mesquita, Bertino, Silva, \& Costa, 2013). A reduction in root dry phytomass accumulation due to salt stress has also been observed in other crops such as cashew (Lima et al., 2020b) and guava (Sá et al., 2016). 

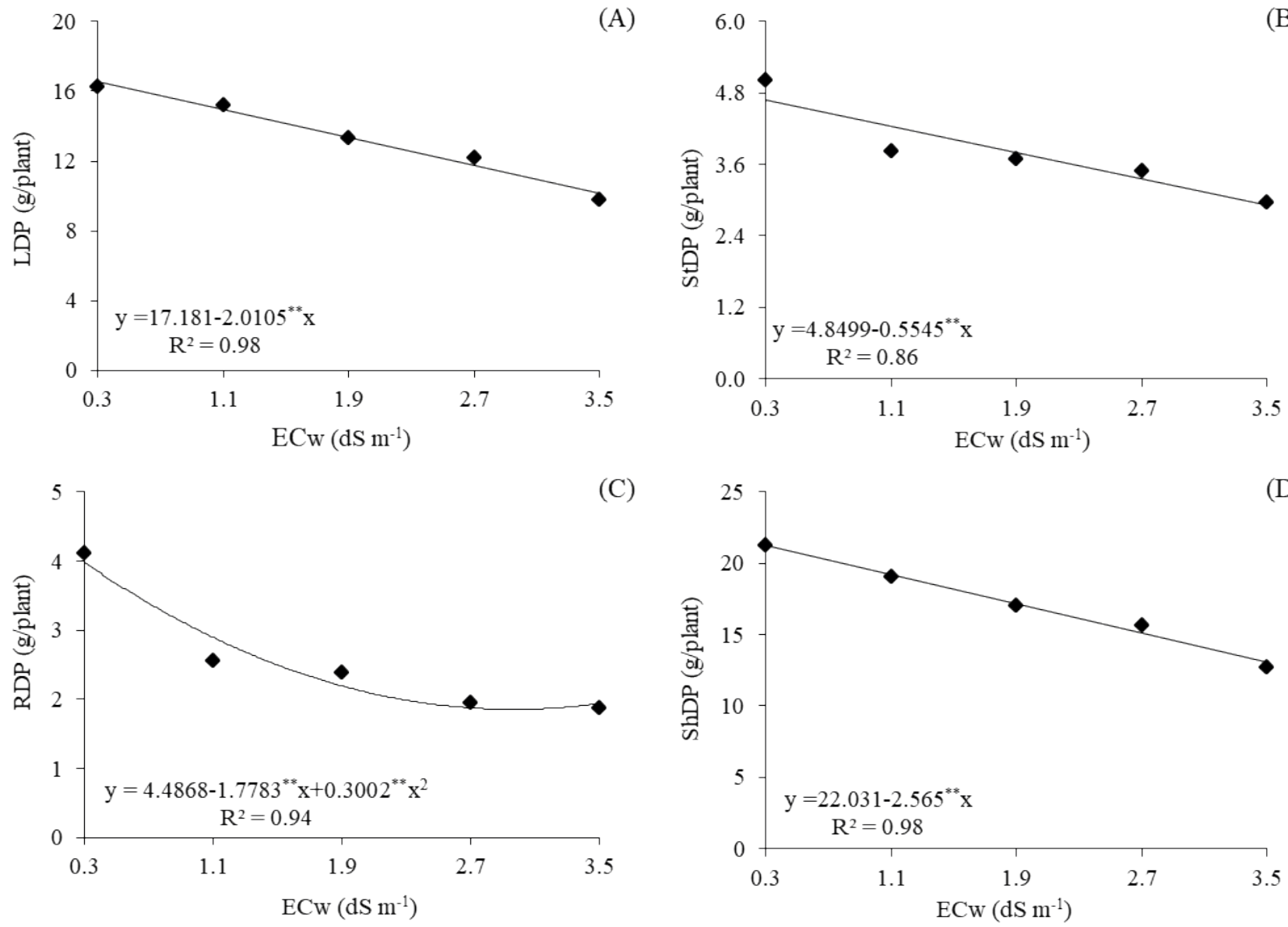

(D)

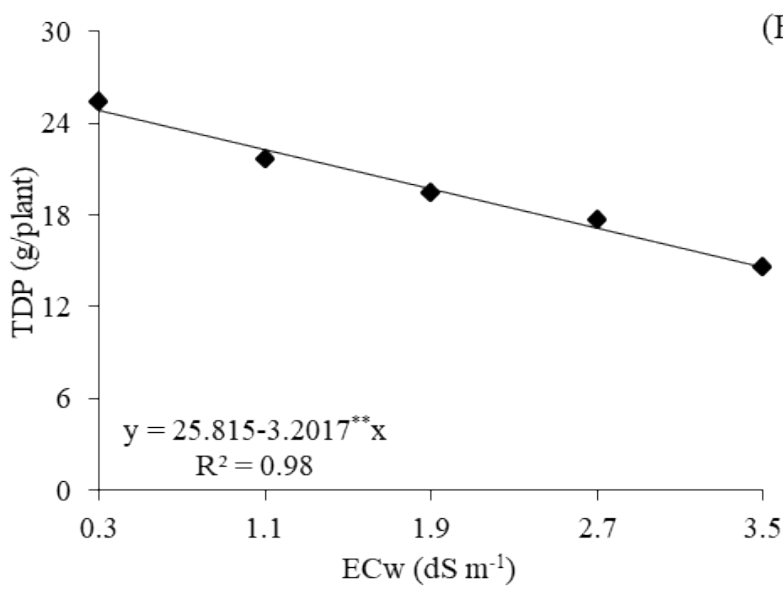

Figure 3. Leaf dry phytomass - LDP (A), stem dry phytomass - StDP (B), root dry phytomass - RDP (C), shoot dry phytomass - ShDP (D) and total dry phytomass - TDP (E) of passion fruit cultivars as a function of water salinity - ECw, at 75 days after sowing.

${ }^{*},{ }^{* *}$ - respectively, significant at $\mathrm{p}<0.05$ and at $\mathrm{p}<0.01$. 
Salt stress also negatively and linearly affected the accumulation of shoot dry phytomass and total dry phytomass and, according to the regression equations (Figure $3 \mathrm{D}$ and $3 \mathrm{E}$ ), there were reductions of 11.64 and $12.40 \%$ per unit increase in ECw, respectively, i.e. the increase in water salinity from 0.3 to 3.5 $\mathrm{dS} \mathrm{m}^{-1}$ reduced the ShDP and TDP of passion fruit by 8.20 and $10.24 \mathrm{~g} /$ plant. The reduction in shoot dry phytomass and total dry phytomass results from the observed decrease in $\mathrm{CO}_{2}$ assimilation rate (Figure 1D) and in the accumulation of leaf dry phytomass (Figure 3A), stem dry phytomass (Figure 3B) and root dry phytomass (Figure 3C) of passion fruit plants. Possibly, the diversion of energy from growth to maintain the metabolic activities of plants associated with the acclimation to salinity and with the reduction in carbon gains may also have contributed to the reduction in growth and, consequently, of phytomass accumulation (Menezes, Azevedo, Ribeiro, \& Cova, 2017). By comparing in relative terms the accumulation of total dry phytomass of passion fruit plants (Figura 3E) subjected to the water salinity level of $3.5 \mathrm{dS} \mathrm{m}^{-1}$ to that obtained under ECw of 0.3 $\mathrm{dS} \mathrm{m}^{-1}$, it was possible to observe reductions of 41.04 and $44.03 \%$, respectively, in the cultivars BRS Sol do Cerrado and Guinezinho. Considering the relative reduction ranges indicated by Richards (1954), the passion fruit cultivars BRS Sol do Cerrado and Guinezinho are classified as moderately sensitive (40$60 \%)$ to water salinity.
The Dickson Quality Index of passion fruit plants was significantly affected by the interaction between the factors $S L$ and $C$ (Figure 4). The DQI of the cultivars BRS Sol do Cerrado and Guinezinho was described by a quadratic trend as a function of the increasing levels of salinity, with the maximum estimated values of 1.334 and 1.306 observed in plants subjected to ECw of $0.3 \mathrm{dS} \mathrm{m}^{-1}$ and the minimum values of 0.736 and 0.494 , respectively, observed in plants that received the highest level of water salinity (3.5 dS m-1). Despite the reduction in $D Q I$ with increase in water salinity levels observed in the passion fruit cultivars, plants subjected to the highest level of ECW (3.5 dS $\mathrm{m}^{-1}$ ) obtained a value higher than 0.4, i.e., the seedlings have an acceptable quality for transplanting to the field.

The Dickson quality index is an integrated morphological parameter and stands out as an indicator of seedling quality, enabling the consideration of robustness and balance in the distribution of phytomass (Costa et al., 2017). Being a morphological variable that is associated with phytomass accumulation (shoot, root and total dry phytomass), the ratio between growth in plant height and stem diameter is considered useful in determining the quality of seedlings for field cultivation. Root dry phytomass accumulation stands out as one of the most important parameters for determining the survival and establishment capacity of seedlings in the field. 


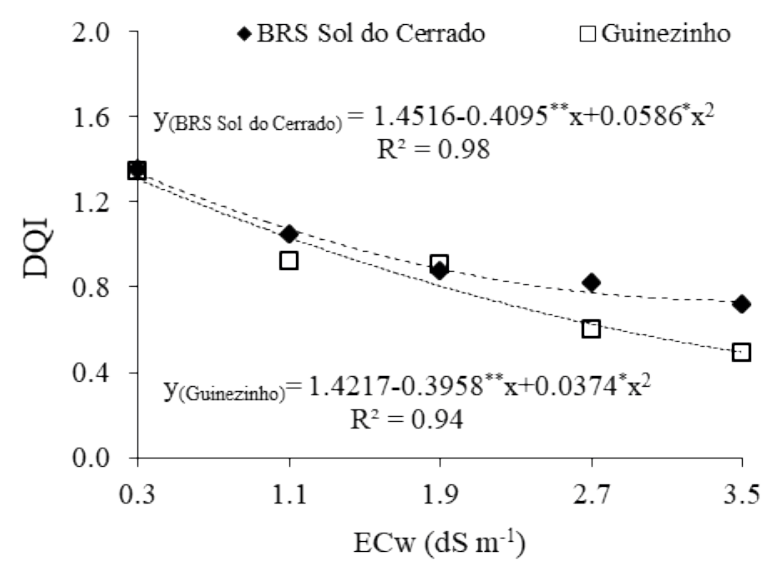

Figure 4. Dickson Quality Index- DQI of passion fruit cultivars as a function of water salinity - ECw, at 75 days after sowing.

${ }^{*},{ }^{* *}$ - respectively, significant at $p<0.05$ and at $p<0.01$.

In this study, the decrease in the production of photoassimilates also resulted in a lower accumulation of ShDP, RDP, and TDP. However, water with electrical conductivity of up to $3.5 \mathrm{dS} \mathrm{m}^{-1}$ can be used in irrigation during the stage of production of passion fruit seedlings, because a DQI above 0.2 (Dickson, Leaf, \& Hosner, 1960) is considered suitable for field cultivation. In a study evaluating the growth and quality of seedlings of two passion fruit cultivars (yellow and purple) under irrigation with saline water $\left(0.5\right.$ and $\left.3.5 \mathrm{dS} \mathrm{m}^{-1}\right)$, Freire and Nascimento (2018) concluded that irrigation with high-salinity water reduced the DQI of yellow passion fruit seedlings and increased the DQI of purple passion fruit seedlings.

\section{Conclusions}

The gas exchange and growth of the passion fruit cultivars BRS Sol do Cerrado and Guinezinho are negatively affected by irrigation using water with electrical conductivity from $0.3 \mathrm{dS} \mathrm{m}^{-1}$, at 75 days after sowing.

Despite the reduction in the growth of passion fruit cultivars, irrigation water of up to $3.5 \mathrm{dS} \mathrm{m}^{-1}$ can be used to obtain passion fruit seedlings with an acceptable quality.

Based on the relative yield of total dry phytomass, the passion fruit cultivars BRS Sol do Cerrado and Guinezinho are classified as moderately sensitive to water salinity up to the level of $3.5 \mathrm{dS} \mathrm{m}^{-1}$.

\section{Acknowledgments}

To the National Council for Scientific and Technological Development (CNPq) for providing the financial assistance (Proc. CNPq 429732/2018-0) and research productivity grant (Proc. CNPq 309127/2018-1) to the first author. 


\section{References}

Acosta-Motos, J. R., Ortuño, M. F., BernalVicente, A., Diaz-Vivancos, P., SanchezBlanco, M. J., \& Hernandez, J. A. (2017). Plant responses to salt stress: adaptive mechanisms. Agronomy, 7(18), 1-37. doi: 10.3390/agronomy7010018

Altuntas, O., Dasgan, H. Y., \& Akhoundnejad, Y. (2018). Silicon-induced salinity tolerance improves photosynthesis, leaf water status, membrane stability, and growth in pepper (Capsicum annuum L.). HortScience, 53(12), 1820-1826. doi: 10.21273/HORTSCI13411-18

Andrade, E. M. G., Lima, G. S. de, Lima, V. L. A. de, Silva, S. S. da, Gheyi, H. R., \& Silva, A. A. R. da. (2019). Gas exchanges and growth of passion fruit under saline water irrigation and $\mathrm{H}_{2} \mathrm{O}_{2}$ application. Revista Brasileira de Engenharia Agrícola e Ambiental, 23(12), 945-951. doi: 10.1590/1807-1929/ agriambi.v23n12p945-951

Bezerra, I. L., Gheyi, H. R., Nobre, R. G., Barbosa, J. L., Fátima, R. T., Elias, J. J., Souza, L. P., \& Azevedo, F. L. (2018b). Physiological alterations and production of guava under water salinity and nitrogen fertilizer application. Semina: Ciências Agrárias, 39(5), 1945-1956. doi: 10.5433/16790359.2018v39 n5p1945

Bezerra, I.L., Nobre, R. G., Gheyi, H.R.,Lima, G.S., \& Barbosa, J.L. (2018a). Physiologicalindices and growth of 'Paluma' guava under saline water irrigation and nitrogen fertigation. Revista Caatinga, 31(4), 808-816. doi: 10.1590/1983-21252018v31n402rc

Bezerra, J. D., Pereira, W. E., Silva, J. M., \& Raposo, R. W. C. (2016). Crescimento de dois genótipos de maracujazeiro-amarelo sob condições de salinidade. Revista Ceres, 63(4), 502-508. doi: 10.1590/0034737X201663040010
Bosco, M. R. de O., Oliveira, A. B. de, Hernandez, F. F. F., \& Lacerda, C. F. de. (2009). Efeito do $\mathrm{NaCl}$ sobre o crescimento, fotossíntese e relações hídricas de plantas de berinjela. Revista Ceres, 56(3), 296-302.

Brito, M. E. B., Fernandes, P. D., Gheyi, H. R., Melo, A. S., Soares Filho, W. S., \& Santos, R. T. (2014). Sensibilidade à salinidade de híbridos trifoliados e outros portaenxertos de citros. Revista Caatinga, 27(1), 17-27.

Cavalcante, L. F., Santos, J. B. dos, Santos, C. J. O., Feitosa Filho, J. C., Lima, E. M. de, \& Cavalcante, I. H. L. (2002). Germinação de sementes e crescimento inicial de maracujazeiros irrigados com água salina em diferentes volumes de substrato. Revista Brasileira de Fruticultura, 24(3), 748-751. doi: 10.1590/S0100 $-29452002000300047$

Chaves, M. M., Flexas, J., \& Pinheiro, C. (2009). Photosynthesis under drought and salt stress: regulation mechanisms from whole plant to cell. Annals of Botany, 103(4), 551560. doi: 10.1093/aob/mcn125

Costa Jr., E. de S., Matias, S. S. R., Sousa, S. J. de C., Soares, G. B. dos S., Morais, D. B. de, \& Nascimento, A. H. do. (2017). Produção de mudas de Carica papaya, tipo formosa, com resíduos de pau de buriti (Mauritia flexuosa L. f.). Revista de Ciências Agrárias, 40(4), 746-755. doi: 10.19084/RCA16152

Dickson, A., Leaf, A. L., \& Hosner, J. F. (1960). Quality appraisal of white spruce and white pine seedling stock in nurseries. Forest Chronicle, 36(1), 10-13. doi: 10.5558/ tfc36010-1

Empresa Brasileira de Pesquisa Agropecuária (2008). Híbrido de maracujazeiro-azedo para mesa e indústria: BRS Sol do Cerrado. Planaltina, DF: Embrapa Cerrados. 
Ferreira, D. F. (2011). Sisvar: A computer statistical analysis system. Ciência e Agrotecnologia, 35(6), 1039-1042. doi: 10.1590/S1413-70542011000600001

Filek, M., Walas, S., Mrowiec, H., RudolphySkórska, E., Sieprawska, A., \& BiesagaKościelniak, J. (2012). Membrane permeabilityandmicro-andmacroelement accumulation in spring wheat cultivars during the short-term effect of salinityand PEG-induced water stress. Acta Physiologiae Plantarum, 34(3), 985-995. doi: 10.1007/s11738-011-0895-5

Freire, J. L. de O., \& Nascimento, G. dos S. (2018). Produção de mudas de maracujazeiros amarelo e roxo irrigadas com águas salinas e uso de urina de vaca. Revista de Ciências Agrárias, 41(4), 981-988. doi: 10.19084/RCA18164

Freire, J. L. de O., Dias, T. J., Cavalcante, L. F., Fernandes, P. D., \& Lima, A. J. de Neto. (2014). Rendimento quântico e trocas gasosas em maracujazeiro amarelo sob salinidade hídrica, biofertilização e cobertura morta. Revista Ciência Agronômica, 45(1), 82-91. doi: 10.1590/ S1806-66902014000100011

Instituto Brasileiro de Geografia e Estatística (2018). Produção agrícola municipal. Recuperado de https:// sidra.ibge.gov.br/ tabela/5457\#resultado

Lima, G.S.de,Fernandes, C.G.J.,Soares, L.A.dos A., Gheyi, H. R., \& Fernandes, P. D. (2020a). Gas exchange, chloroplast pigments and growth of passion fruit cultivated with saline water and potassium fertilization. Revista Caatinga, 33(1), 184-194. doi: 10.1590/1983-21252020v33n120rc

Lima, G. S. de, Silva, J. B. da, Soares, L. A. dos A., Gheyi, H. R., Nobre, R. G., \& Souza, L. de P. (2020b). Physiological indices and phytomass partition in precocious dwarf cashew clones irrigated with saline waters. Comunicata Scientiae, 11(1), e3196. doi: 10.14295/cs.v11i0.3196

Mastrogiannidou, E., Chatzissavvidis, C., Antonopoulou, C., Tsabardoukas, V., Giannakoula, A., \& Therios, I. (2016). Response of pomegranate cv. Wonderful plants to salinity. Journal of Soil Science and Plant Nutrition, 16(3), 621-636. doi: 10.4067/S0718-95162016005000032

Medeiros, S. A. S., Cavalcante, L. F., Bezerra, M. A. F., Nascimento, J. A. M. do, Bezerra, F. T. C., \& Prazeres, S. S. (2016). Água salina e biofertilizante de esterco bovino na formação e qualidade de mudas de maracujazeiro amarelo. Irriga, 21(4), 779-795. doi: 10.15809/ irriga.2016v21n4p779-795

Medeiros, J. F. (1992). Qualidade da água de irrigação e evolução da salinidade nas propriedades assistidas pelo GAT nos Estado do RN, PB e CE. Dissertação de mestrado em Engenharia Agrícola, Universidade Federal da Paraíba, Campina Grande, Brasil.

Menezes, R. V., Azevedo, A. D. de, Neto, Ribeiro, M. de O., \& Cova, A. M.W. (2017). Growth and contents of organic and inorganic solutes in amaranth under salt stress. Pesquisa Agropecuária Tropical, 47(1), 22-30. doi: 10.1590/1983-40632016v4742580

Mesquita, F. de O., Batista, R. O., Cavalcante, L. F., Souto, A. G. de L., Lima, A. J. de, Neto, \& Oliveira, C. J. de. (2015). Efeito salino da água e da aplicação de biofertilizante sobre o crescimento do mamão Havaí. Magistra, 27(2), 208-216.

Novais, R. F., Neves, J. C. L., \& Barros, N. F. (1991). Ensaio em ambiente controlado. In A. J. Oliveira (Ed.), Métodos de pesquisa em fertilidade do solo (pp. 189-253). Brasília: EMBRAPA Informação Tecnológica. 
Oliveira, F. A., Medeiros, J. F. de, Oliveira, M. K. T., Souza, A. A. T., Ferreira, J. A., \& Souza, M. S. (2013) Interação entre salinidade e bioestimulante na cultura do feijão caupi. Revista Brasileira de Engenharia Agrícola e Ambiental, 17(5), 465-471, 2013. doi: 10.1590/S1415-43662013000500001

Richards, L. A. (1954). Diagnosis and improvement of saline and alkali soils. (Agriculture Handbook, 60). Washington: U. S. Department of Agriculture.

Sá, F. V. da S., Mesquita, E. F., Bertino, A. M. P., Silva, G. A., \& Costa, J. D. (2013). Biofertilizantes na produção hidropônica de mudas de mamoeiro. Revista Verde de Agroecologia e Desenvolvimento Sustentável, 8(3), 109-116.

Sá, F. V. da S., Nobre, R. G., Silva, L. de A., Moreira, R. C. L., Paiva, E. P. de, \& Oliveira, F. A. de. (2016). Tolerance of guava rootstocks under salt stress. Revista Brasileira de Engenharia Agrícola e Ambiental, 20(12), 1072-1077. doi: 10.1590/1807-1929/ agriambi.v20n12p1072-1077
Silva, A. A. R. da, Lima, G. S. de, Azevedo, C. A. V. de, Gheyi, H. R., Souza, L. de P., \& Veloso, L. L. de S. A. (2019). Gas exchanges and growth of passion fruit seedlings under salt stress and hydrogen peroxide. Pesquisa Agropecuária Tropical, 49(1), e5567. doi: 10.1590/1983-40632019v4955671

Silva, E. N. da, Ribeiro, R. V., Ferreira-Silva, S. L., Viégas, R. A., \& Silveira, J. A. G. (2011). Salt stress induced damages on the photosynthesis of physic nut young plants. Scientia Agricola, 68(1), 62-68. doi: 10.1590/S0103-90162011000100010

Teixeira, P. C., Donagemma, G. K., Fontana, A., \& Teixeira, W. G. (Org.). (2017). Manual de métodos de análise de solo (3a ed.). Brasília, DF: EMBRAPA.

Willadino, L., Gomes, E. W. F., Silva, E. F. de F., Martins, L. S. S., \& Camara, T. R. (2011). Efeito do estresse salino em genótipos tetraplóides de bananeira. Revista Brasileira de Engenharia Agrícola e Ambiental, 15(1), 53-59. doi: 10.1590/ S1415-43662011000100008 
